\title{
The Eternal Quest for Feminine Identity: An Analysis of Isabel Allende's Daughter of Fortune
}

\section{OPEN ACCESS}

Manuscript ID:

ENG-2021-09033909

Volume: 9

Issue: 3

Month: June

Year: 2021

P-ISSN: 2320-2645

E-ISSN: 2582-3531

Received: 18.04.2021

Accepted: 26.05.2021

Published: 01.06.2021

\section{Citation:}

Aravindan, Anjely. "The Eternal Quest for Feminine Identity: An Analysis of Isabel Allende's Daughter of Fortune." Shanlax International Journal of English, vol. 9, no. 3, 2021, pp. 57-60.

DOI:

https://doi.org/10.34293/ english.v9i3.3909

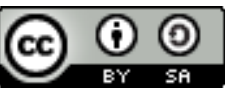

This work is licensed under a Creative Commons Attribution-ShareAlike 4.0 International License

\author{
Anjely Aravindan \\ Assistant Professor, Al-Azhar College of Arts and Science, Thodupuzha, Kerala, India \\ https://orcid.org/0000-0002-2430-9868
}

\begin{abstract}
The objective of this paper is to mirror the feminine quest for freedom, self-discovery, identity, revelation and the declaration of equal status along with their male counterparts in society. Hence, it does not justify the male domination which tries to establish a right to impose their will upon the fellow-creature. Feminism is a theory that investigates the various aspects of culture which are inherently patriarchal and the unequal treatment meted out to the women in the established sections of society. Isabel Allende's Daughter of Fortune points out the various aspects of feminism through the portrayal of the hostile atmosphere where the women strive for their eternal quest for freedom and self-identity. The paper also intends to analyze and explain the transition of a young girl into a powerful woman figure which is indicative of the inner strength and power of the living spirit which is inherited in each woman. Eliza acts as a representative who stands against the constricting forces of patriarchy. This points out the ability of the woman to come out of their cocoons to explore the world. It asserts the value of every woman's self-identity. The paper analyses how the "quest" of Eliza turns out to be the quest of the woman folk for genuine freedom and self-identity.
\end{abstract}

Keywords: Feminism, Latin American literature, Daughter of Fortune, Patriarchy, Isabel Allende, Self-discovery

Feminist theory is by no means a homogeneous body of argument and speculation and if one discerns a common strand in the great diversity of the feminist scholarship, it is its critique of the patriarchal modes of thinking and its political approach to literature and literary criticism. In its diversity feminism is concerned with women being relegated to a secondary position. Feminism can be seen as one of the most significant economic, cultural, social and aesthetic revolutions of the modern era. The Chilean American writer Isabel Allende with her extraordinary imagination and storytelling skills stands apart as a powerful presence who voices her feminine concerns through her protagonists. In the novel Daughter of Fortune, her protagonist undergoes a transition from a meek young girl into a powerful woman figure, which is indicative of the innate inner strength and power of living spirit in each woman. Eliza, the protagonist, seems to be a living model for real womanhood who through her thoughts and deeds opened up a new unexplored path for womenfolk. She ran away from the safety of her home in Chile, travelled alone in the hold of the ship where she almost died and then crisscrossed California for years looking for the man she loved. She did not find him but instead, she found something more valuable: Freedom. 
Being born as a woman on earth does not seem to be a challenging issue for Eliza Sommers, one of the most powerful women characters who seek her destiny through hardcore struggles. Her life itself is a voyage rich in symbols of a developing woman who rebels against a confining patriarch and then fills the void with a new definition of self. She stands as a representative of womenfolk who wishes to turn blind against the dark realities of the patriarchal system which barricaded its boundaries with strict rules and rigid disciplines. Instead of projecting helplessness as the typical feminine behaviour, Isabel Allende tries to portray a strong-willed woman who pursues her dreams with determination and intelligence. Eliza not only seeks status as an independent and responsible woman but also wishes to attain selfhood. Rather than restricting herself into married life, she explored her realities and set out free from the clutches of society. Eliza's quest for self-hood and freedom to pursue her plans comes into a conflict with the societal intention to restrict her growth and confines her into the four walls of domestic life but she decides to follow her calling, ignoring the norms stipulated by society.

She was moulded by her adoptive parent figures who believed that the best possible future for her is to be kept by a man. Her status in society is much better than "other" womenfolk as her adopted parents provided her with a better and standard education. She was taught French, Writing, History, Geography and a little Latin. This education is going to help her in the future to survive in a new land of complexities and confusion. Eliza's life is woven around Sommers's family where she has to face the dark realities of male domination. She has to deal with not only the male patriarch of the family, Jeremy and John Sommers but also the female subordinate Miss Rose who tries to implement her wishes upon Eliza.

Miss Rose, Eliza's foster mother tries to mould her into a perfect feminine English maid. The young girl resisted such attempts but felt disturbed by the restrictions and disapprovals. Miss Rose tries to impose her whims and fancies upon Eliza. She is not at all concerned about the hopes, aspirations, likes and dislikes of Eliza but rather imposes her ways of life upon Eliza. She is inconsiderate of the mental struggles and conflicts within Eliza. For instance, the day Eliza threw a tantrum because she did not want to practice the piano, Miss Rose terrified her that she will enroll her in the Foundling Home for the Orphans. She persuaded her to practice piano and Eliza being afraid of Miss Rose's temper, learned to play the piano without talent or grace. Miss Rose played a crucial role in shaping Eliza's character and mindset.

Eliza has to first deal with Miss Rose who insists on dressing her in fancy clothes to impress her societal friends. Eliza has been imprisoned within the expensive dresses and she is unable to move around the house like the playful child that she is. As she grows older, she must wear a corset, tightly strung and stiffly reinforced bodice that artificially creates a small waist and high raising bosom. Miss Rose believes that these are the essential feminine features to attract men.

Women are the progenitors as well as the victims of patriarchal institutions. The tragedies of women often follow from their character because they are responsible for giving consent to patriarchy. There are several instances in the novel where Miss Rose considers herself as an inferior character who is supposed to live under the control of man. She thinks that a single woman of her age had no future in society. There are several situations in the novel which exposes the character and mindset of Miss Rose such as "You must allow the man to feel superior, child. Miss Rose patiently explained. That is very difficult, Eliza unmoved responded", "No woman with an ounce of sense gets married to be entertained, she marries to be maintained", "We are women, and that is our cross. All we can do is try to get the best from the little we have".

The patriarchal structures enclosed women in the private space of the home where they led inert and useless lives. From childhood, girls are taught selfeffacement and modesty. The predicament of every woman including Eliza is so harsh that they are not even allowed to choose their life partners. In Eliza's case, Miss Rose wants her to marry a "congenial and wealthy husband". But Eliza against Miss Rose's wish already obsessed with Joaquin Andieta, an illegitimate son and a poor man who tries hard to seek a better fortune for himself and his dishonoured mother. Eliza sacrifices her honour, her most 
precious treasure without which she had no future, for him as she aspires to serve him wholeheartedly for the rest of her life. She is ready to sacrifice herself and suffers to prove her selflessness and is even ready to die for him if necessary. Joaquin like the majority of males had abandoned her in search of his new fortunes during the gold rush in California. The novelist is justifying her protagonist's situation by stating that it was not Eliza's fault that she fell in for the first man to cross her path but her pent-up frustrations over her restrictions and subordination, venture out through the medium of love.

She acquired the confidence to seek the help of a gentle Chinese doctor Tao Chi'en and stows away on a ship packed with sailors, adventures, whores bound for the harsh frontier town of San Francisco. "Because he had never seen a woman capable of such extremes in real life, only in classic novels, in which the heroines always died at the end", Tao Chi'en was amazed at her valiant determination and his initial surprise gradually turned into frank amazement after witnessing Eliza's brave deeds.

But during her journey, she had to suffer a lot, from seasickness to miscarriage. But she with her strong passion and sheer determination survived, as a premature death was not her karma. To leave the ship without suspicion, Tao disguises Eliza as a Chinese boy and she in her male outfits starts her journey towards the revelation of her identity as a woman. She pretends to be a deaf-mute Chinese boy at one point and the brother of her Chilean lover, Elias Andieta at another point. Thus, she invents and reinvents her identities to accommodate the changing situations. There are many shreds of evidence in the novel which brings out the essence of feminism through the vivid portrayal of Eliza's new life and her quest for freedom.

She fell in love with freedom. In the Sommers home she had lived shut up within the four walls, in a stagnant atmosphere where time moved in circles and where she could barely glimpse the horizon through distorted windowpanes. She had grown up as a clad in the impenetrable armor of good manners and convention, trained from childhood to please and serve, bound by corset, routines, social norms and fear. Fear had been her companion: fear of God and his unpredictable justice, of authority, of her adoptive parents, of illness and evil tongues, of anything unknown or different, fear of leaving the protection of her home and facing the dangers outside; fear of her own fragility as a woman, of dishonor and truth. (Allende)

Her hidden desire to escape from the mundane existence and the feminine quest for freedom, to make her body and soul free from the powerful will that bends her determination are evident from these lines. She was now finding new strength in herself. She has changed both physically and mentally by reinventing her female identity. Her eternal quest for self-identity spreads its wings and begins to fly across the new land, restless. She has learned new languages, met new people, faced new situations and learned to live for the day, without making plans. She has lost her horror of blood, learned to stitch human flesh, wandering around freely to enjoy the freshness of each place, made friends and was satisfied with her present condition. Eliza along with Tao sets up a network to help young Chinese prostitutes to escape and rehabilitate.

Eliza aspires to become one of those individuals who are proud; with no one above them except sky overhead and they bow to no one as they uphold equality. After gaining deeper knowledge about those people who believed that they are the masters of their destiny, she can never again be the lady Miss Rose intended her to be. Now, for her freedom was euphoria, light and happiness as intense as true love. Her revelation, "It is tedious to be a man, but being a woman is still worse" is suggestive of the feminine revelation about the equal status shared by both men and women and the need to work hand in hand in society.

From Eliza's memory, Joaquin Andieta began to fade away and the mission of finding her lover changed into something else; a real passionate yearning for freedom and self-identity. She is now aware of the supreme truth that the direction she chose would determine the rest of her life. Eliza regains her womanhood even in her appearance and soon after Joaquin Murieta is shot dead, Eliza and Tao decided to live together and thus she declared her lifelong freedom. The novel however ends with Eliza's powerful declaration about her lifelong freedom "I am free". This declaration of Eliza being "free" can be interpreted vividly from the feminist point of view. It can be the freedom from the haunting 
thoughts of her lover who stands as a representative of all men who betray women, freedom from the magical spells of adolescent love affairs, freedom from the patriarchal norms, notions, restrictions, rigid rules and disciplines stipulated by the society. Eliza thus redefined the sense of womanhood and explored her freedom and self-identity.

Isabel Allende had succeeded in exploring her Feminist concerns through the narrative folds of Daughter of Fortune. The novel seems to be a sincere effort on the part of the novelist to express her frustrations about the identity crises of womenfolk. Women are bound to suffer as long as they are ready to confine to their limited space. Eliza's eternal quest for self-identity proves to be the right path for the woman who aspires to be free from the clutches of society. Feminism is gaining wide acclaim even in the present era and Eliza can be considered as a torchbearer for the new beginning in the life of feminists. Her "quest" gradually turns out to be the quest of every woman in the world. She had succeeded in satisfying her thirst for freedom and self-identity through strong passion and sheer determination and she is celebrating her life in its full spirit. This can be seen as the crux of feminism which declares every woman to explore life to the fullest with the help of their unique and powerful living spirit within them.

\section{References}

Allende, Isabel. Daughter of Fortune. Harper Perennial Publication, 2008.

André, María Claudia. "Breaking through the Maze: Feminist Configurations of the Heroic Quest in Isabel Allende's Daughter of Fortune and Portrait in Sepia." Latin American Literary Review, vol. 30, no. 60, 2002, pp. 74-90.

Brooker, Peter. A Glossary of Cultural Theory. Hodder Publication, 2003.

Buchanan, Ian. Oxford Dictionary of Critical Theory. Oxford University Press, 2010.

Dewita, Famela. Isabel Allende and Her Feminist Thoughts in Daughter of Fortune. Andalas University, 2011.

Kurien, Shobhana. Breaking the Silence: An Anthology of Women's Literature. Ane Books, 2012.

Malpas, Simon, and Paul Wake. The Routledge Companion to Critical Theory. Routledge, 2006.

Moi, Toril. Sexual/ Textual Politics. Routledge, 1985.

Showalter, Elaine. A Literature of Their Own: From Charlotte Brontë to Doris Lessing. Virago, 1999.

\section{Author Details}

Anjely Aravindan, Assistant Professor, Al-Azhar College of Arts and Science, Thodupuzha, Kerala, India,

Email ID: anjely461@gmail.com 